\title{
대 라오스 원조 현황
}

우리나라의 대라오스 무상원조 지원규모는 라오스 전체 수원금액 중 $2.63 \%$ 에 달하며 순위로는 11 위 의 공여국에 해당된다.(2005-2006년: 11위, 2004-2005년: 9위) 라오스는 인도네시아, 베트남, 스 리랑카, 필리핀, 캄보디아에 이어 $\mathrm{KOICA}$ 의 아시아지역 상위 6 대 수원국가이고 이러한 라오스에서 우리나라가 아닌 다른 공여국 및 공여기관에서는 어떻게 원조를 집행하는지 살펴보는 것은 의미가 있다고 본다. [ 정리 : 정책연구실 ]

\section{1. 라오스 2005/2006년 라오스 무상원조 공여국 순위 및 주요지원 분야}

\begin{tabular}{|c|c|c|c|c|}
\hline 순 위 & 국 가 명 & 금액(백만달러) & 비 율 & 주요 지원 분야 \\
\hline 1 & 일본 & 62.18 & 27.83 & $\begin{array}{l}\text { • 교통(도로건설) } \\
\text { • 천연자원 개발 } \\
\text { • 보건 } \\
\text { • 행정능력 함양 } \\
\text { • 재난방지 } \\
\text { • 보건 }\end{array}$ \\
\hline 2 & 베트남 & 24.86 & 11.13 & $\begin{array}{l}\text { - 교통(도로건설) } \\
\text { - 인적자원 개발 } \\
\text { - 농림업 } \\
\text { - 교통 } \\
\text { - 천연자원 개발 }\end{array}$ \\
\hline 3 & 중국 & 21.16 & 9.47 & $\begin{array}{l}\text { • 교통 } \\
\text { • 인적자원 개발 } \\
\text { • 통신 }\end{array}$ \\
\hline
\end{tabular}




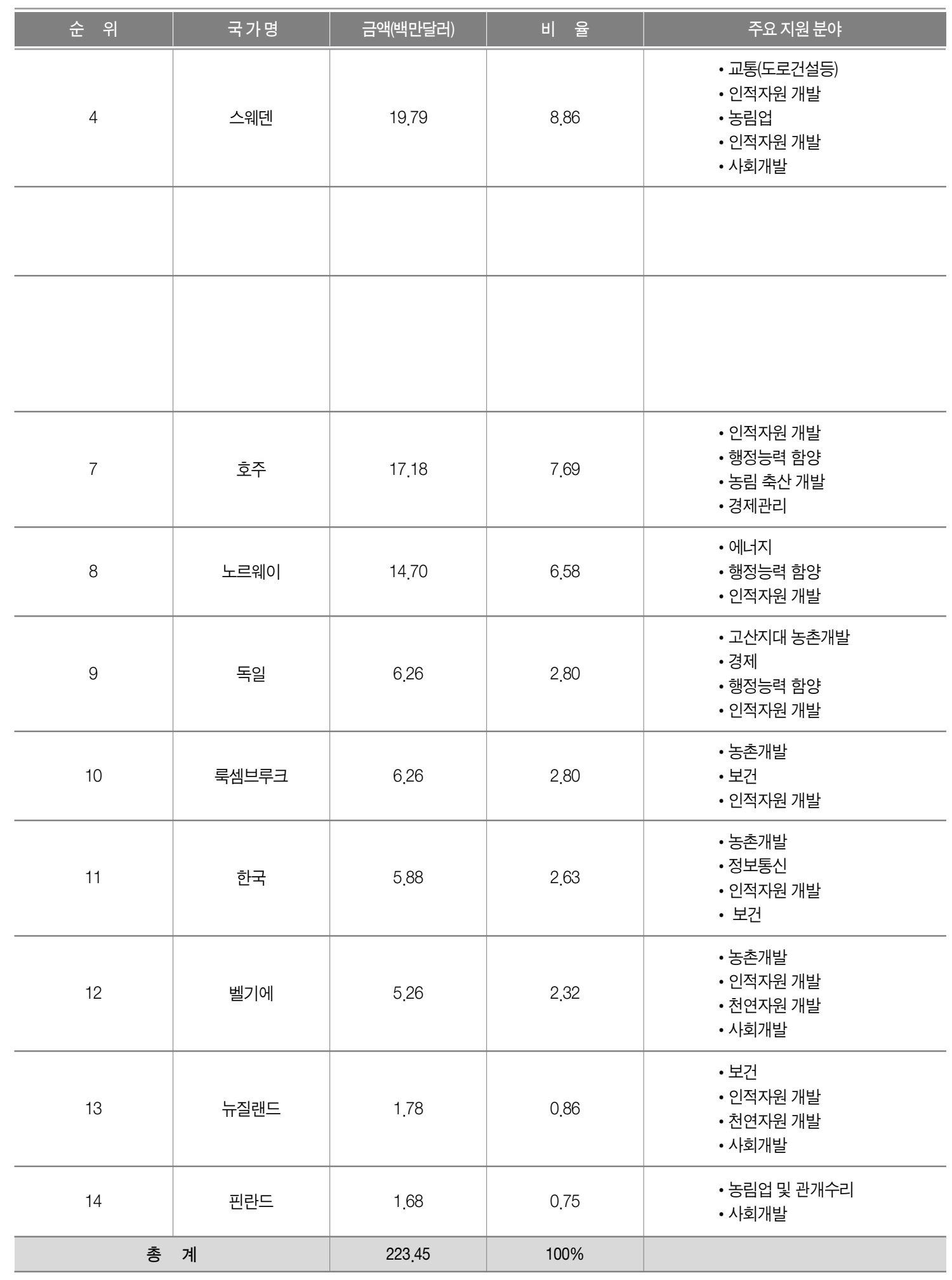




\section{2. 주요 공여국 및 국제기구}

\section{가. 주요 공여국}

\section{- 일본}

() 일본 NGO 홍역백신 지원

1994년 설립되어 아시아 지역에 소아마비 등 백신 지원활동을 하는 일본 NGO "Vaccinates for the world's children"가 라오스에 홍역백 신 구입을 위하여 10 만 달러를 지원함. 라오스 의 연간 인구 성장률 $2 \%$ 를 기록하고 있고 유 아사망률, 모성사망률이 높아 주재국 보건부 에서도 동 사망률 감소를 위하여 의료진 예방, 전통의학과 현대의학 접목, 보건 분야 발전을 위한 대중의 참여 유도, 보건소의 의료서비스 질 향상 등 5 단계 질병퇴치 전략을 수립하여 시행하고 있음

\section{- 미국}

(2) 미폭발물(UXO) 피해지역 초등교육 분야 지원 미국은 인도차이나 반도 전쟁시 폭격피해를 입었던 9 개주를 대상으로 초등교육 분야에 10 만 달러를 지원하여 씨엥쿠앙, 후아판, 루앙프 라방, 캄무안, 사바나켓, 참파삭, 사라완, 세콩 등 초등학교 교사연수, $\mathrm{UXO}$ 예방을 위한 포스 터 제작 활동을 할 계획임. 동 프로젝트는 1997년부터 시작되어 현재까지 37 개군 1,500
개의 초등학교에 지원되었음.

\section{- 독일}

(0) 라오스 고문서 복원 지원

독일정부는 지난 6 년간 라오스 국립도서관을 통하여 고문서 복원을 지원해 왔으며 각 지방 별로 순회하며 고문서에 대한 현황을 조사하 고 있음. 동 조사를 통하여 각 지방 사찰에서 보유하고 있는 코코낫 나뭇잎에 씨여진 고문 서를 비롯하여 각종 국가차원의 보존가치가 있는 유물들도 다수 발견됨

() WFP(World Food Program) 지원 독일이 라오스 기아구제를 위하여 $\mathrm{WFP}$ 를 통 하여 4.3 백만달러를 지원하였음. 독일은 2007년도에만 WFP에 60백만 달러를 지원, $\mathrm{WFP}$ 의 10 대 공여국 중의 하나임. 금번 지원 금으로 WFP는 주재국내 홍수피해, 마약재배 포기농가 70 만 달러를 지원할 계획임. 또한 쌀 1,000 톤을 식량생산 및 도로건설, 양어, 벼 재배 등 WFP 프로그램 참여한 농가에 지 원할 계획임. 독일은 라오스 이외에 아프가니 스탄 학교 급식 프로그램, 남아프리카 식량도 지원함

() UNDOC을 통한 마약재배 포기 농가 지원 독일과 UNDOC(the United Nations Office on the Drugs and Crimes)이 130만 유로를 
퐁살리주 마약재배 포기 농가에 농가소득 증 대 프로젝트에 지원함. 동 프로젝트는 2010년 까지 실시될 예정이며 마약재배 포기로 생계 유지가 곤란한 농가를 지원하기 위한 것임. 동 지역은 1998 년 이래 2,056 가구가 생계유지를 위하여 마약을 재배하였으며 주재국 정부의 마약 재배지 근절 노력으로 $93 \%$ 의 마약 재배 지가 감소되었음

\section{나. 국제기구 및 NGO}

\section{- 세계은행 라오스 빈곤퇴치에 15 백만 달러 무상지원}

세계은행은 2008년부터 3년동안 2단계 빈곤 퇴치사업에 15 백만 달러를 지원하기로 함. 동 지원금은 라오스내 후아판, 시엥쿠앙, 사바나 켓, 살라완, 참파삭등 14 개 최빈군을 대상으로 지원할 예정이며 인프라 개선, 지방정부의 행 정능력 제고가 사업 내용에 포함되어 있음. 2003-2007년간 1단계 사업으로 354개 학교 개보수, 20 만 학생의 학교진학, 인프라 개선 등을 지원함. 그러나 주재국 당국은 동 지역 완전한 빈곤퇴치를 위하여는 81백만 달러의 예산이 필요하다고 전망하고 있어 외부로부터 지원이 더 필요한 실정임
FAO(UN's Food and Agriculture Organization)가 라오스 농가 소득 증대를 위 하여 빈농을 대상으로 채소 및 과실수 재배를 위한 기술지도를 실시하고 있으며 건기와 우 기 등 계절별로 작물 경작에 필요한 기술전수 를 실시하여 농민이 직접 새로운 기술을 접목 시켜 재배를 실시하는 방식으로 신기술을 보 급하고 있음. 2004년부터 실시된 동 프로젝트 에는 81만 불이 투입되어 금년 12 월에 사업이 완료될 예정임. 농림부산하 국가농림연구소가 주도적으로 동 프로젝트에 참여하여 700명의 농민 교육연수 및 48개 시범포를 설립하였음

(0) Save the children Australia (SCA) 사야부리주 기초보건분야 지원 1992년부터 시작되어 현재 3단계에 접어 든 $\mathrm{SCA}$ 의 기초 보건 분야 지원 사업은 사야부리 주 홍사, 눙, 씨엥홍, 콥군의 동 분야 MDGs 달성률을 $80 \%$ 로 끌어 올림. $\mathrm{SCA}$ 는 금년에 동 프로젝트에 13 만 5천불을 투입하여 조산사 양 성, 가족계획, 산모 정기 건강검진 지원하였으 며 국가 전체 10 만 명당 모성사망률 530 명 대 비 동 지역의 모성사망률은 110 명으로 현저하 게 감소하였고 영아사망률도 1 분기 라오스 전 국 영아 사망률인 1,000 명당 29 명 대비 동 지 역의 사망률은 23 명으로 낮은 수준임

[자료:주라오스대사관] 



\section{국제개발협력 2007년 제4호}

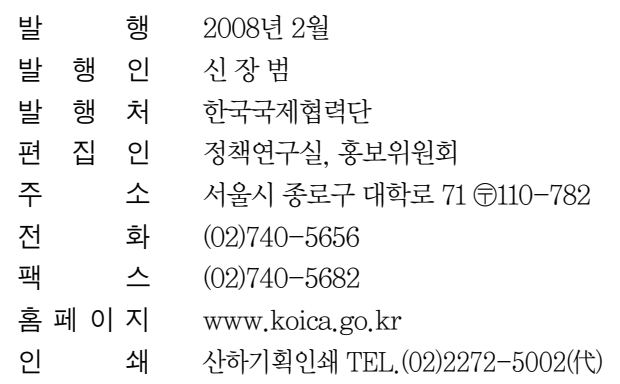

